University of Nebraska - Lincoln

DigitalCommons@University of Nebraska - Lincoln

2018

\title{
Landscape Transformation During Ceramic Age and Colonial Occupations of Barbuda, West Indies
}

\author{
Allison Bain \\ Anne-Marie Faucher \\ Lisa M. Kennedy \\ Allison R. LeBlanc \\ Michael J. Burn
}

See next page for additional authors

Follow this and additional works at: https://digitalcommons.unl.edu/global

Part of the Anthropology Commons, Geography Commons, and the International and Area Studies Commons

This Article is brought to you for free and open access by the School of Global Integrative Studies at DigitalCommons@University of Nebraska - Lincoln. It has been accepted for inclusion in Global Studies Papers \& Publications by an authorized administrator of DigitalCommons@University of Nebraska - Lincoln. 


\section{Authors}

Allison Bain, Anne-Marie Faucher, Lisa M. Kennedy, Allison R. LeBlanc, Michael J. Burn, Rebecca Boger, and Sophia Perdikaris 


\title{
Landscape Transformation During Ceramic Age and Colonial Occupations of Barbuda, West Indies
}

\author{
Allison Bain, ${ }^{1}$ Anne-Marie Faucher, ${ }^{1}$ Lisa M. Kennedy, ${ }^{2}$ \\ Allison R. LeBlanc, ${ }^{2}$ Michael J. Burn, ${ }^{3}$ Rebecca Boger, ${ }^{4}$ \\ and Sophia Perdikaris ${ }^{5}$
}

\author{
1 CELAT Research Centre, Université Laval, Québec, Canada; \\ 2 Department of Geography, Virginia Tech, Blacksburg, VA, USA; \\ 3 Department of Geography and Geology, The University of the West Indies, \\ Kingston, Jamaica; \\ 4 Department of Earth and Environmental Sciences, City University of New \\ York, Brooklyn, NY, USA; \\ 5 Department of Anthropology, City University of New York, Brooklyn, NY, USA \\ Contact - Allison Bain, allison.bain@hst.ulaval.ca CELAT Research Centre, Université \\ Laval, 1030, Avenue des Sciences-Humaines, Québec, Québec G1V oA6, Canada
}

ORCID Michael J. Burn http://orcid.org/0000-0003-1362-6320

\begin{abstract}
This research documented the history of landscape transformation on the island of Barbuda in the Lesser Antilles, Caribbean through cross-disciplinary research approaches. Excavations confirmed a human presence for the seasonal exploitation of conch meat and other mollusks during the Archaic Age (c.3000-500 BC), but more substantial impacts to terrestrial ecosystems likely began during the Ceramic Age (c.500 BC-AD 1500). Our combined sedimentary and charcoal records revealed that
\end{abstract}

Published in Environmental Archaeology, 2018 VOL. 23, NO. 1, 36-46.

doi:10.1080/14614103.2017.1345115

Copyright (C) 2017 Association for Environmental Archaeology; published by Routledge/

Taylor \& Francis Group. Used by permission.

Submitted 2 November 2016; accepted 25 May 2017; published 7 July 2017. 
human-induced environmental transformations began with Ceramic Age peoples as they cleared vegetation for settlements and gardens with intentional burning. Sedimentary charcoal indicated a dramatic decline in fire during post-Ceramic Age abandonment, continuing through the Colonial Period, as the dominant human activities shifted to herding, farming, and selective wood harvesting. Historical sources showed that during the Colonial Period (post-1492), the island was intermittently settled until the mid-seventeenth century, while the Codrington family of Antigua held the lease to the island from 1681 to 1870 . They used the island for farming and stock-rearing, exporting meat and draught animals along with lime, timber, and subsistence crops. Macrocharcoal recovered from Colonial Period archaeological sites reflect the use of a variety of local species and wood imported to the island or harvested from shipwrecks.

Keywords: Barbuda, pre-Columbian, charcoal, Colonial Period

\section{Introduction}

Human settlement patterns and landscape histories in the Caribbean are influenced by both environmental dynamics and human agency. Establishment of sugar and coffee plantations led to extensive vegetation clearing on many Caribbean islands in the seventeenth century (Armstrong 2013; Hauser and Hicks 2007; Watts 1987). Fitzpatrick and Keegan (2007), however, suggest that landscape changes began much earlier with Ceramic Age horticulturalists who exploited the region's abundant marine resources (Keegan, Hofman, and Rodríguez Ramos 2013). On Barbuda, we used a cross-disciplinary approach combining methods of environmental archaeology and paleoecology to document the nature and extent of these proposed transformations.

This project examined long-term patterns of human-environment interactions on Barbuda (Figure 1). Our objective was to document anthropogenic landscapes by investigating pre-Columbian and Colonial Period charcoal signatures from both archaeological and sedimentary contexts. We also drew upon archival sources (Codrington Papers 2016; Tweedy 1981) to enhance our understanding of the Colonial Period. While archeobotanical studies are increasingly common in Caribbean archaeology (Britt 2010; Newsom 2006, 2008; Newsom and Pearsall 2003; Newsom and Wing 2004; Pagán-Jiménez 2011, 2013), charcoal analysis is underexploited despite its presence in archaeological contexts across all phases of human occupation (Newsom 2006). As such, this is one of the first studies in the region that combines the 


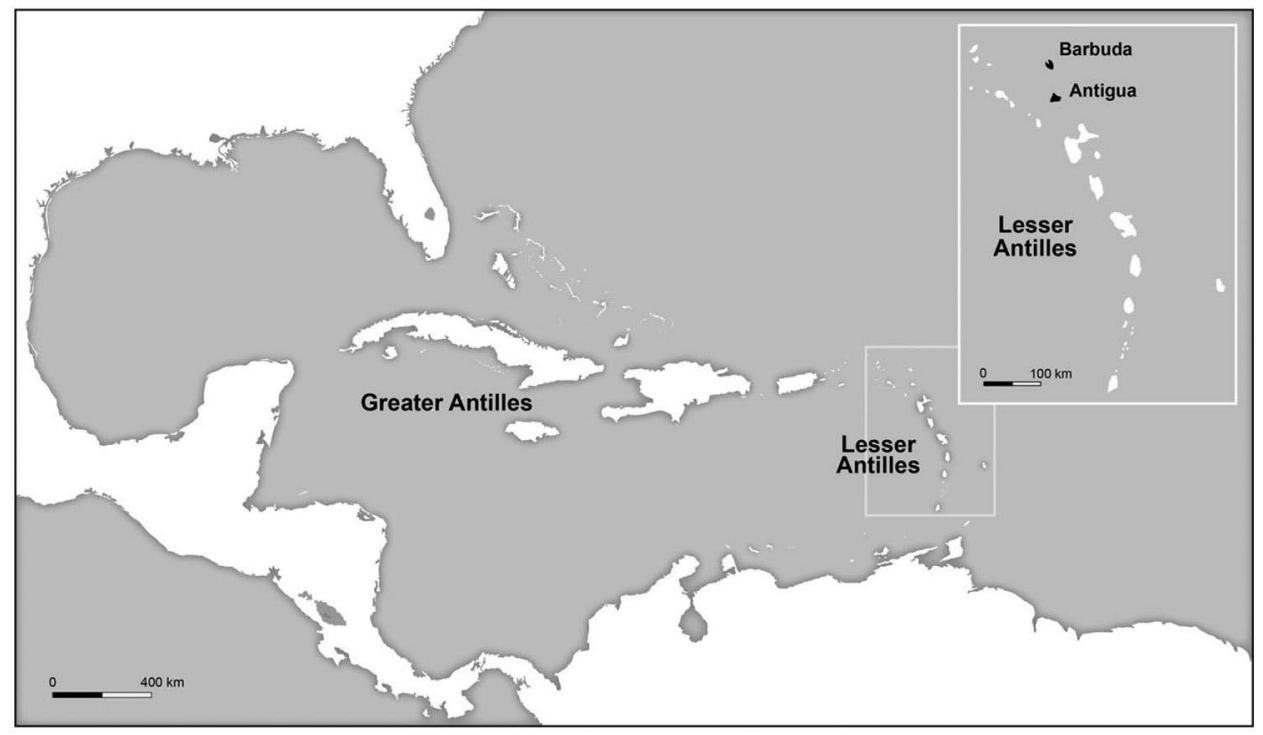

Figure 1. Map of the Caribbean featuring Antigua and Barbuda.

results of both sedimentary and archaeological macrocharcoal analyses. We identified and compared wood exploitation and vegetation changes on Barbuda based on charcoal analyses of four archaeological sites and a sediment core recovered from Freshwater Pond in the southern sector of the island.

\section{Barbuda's Climate and Vegetation}

Barbuda is a low, flat limestone island of $160 \mathrm{~km}^{2}$, with thin soils and limited fresh surface water. Occupying most of the eastern portion of the island, a limestone plateau known as the Highlands represents the island's highest point ( $45 \mathrm{~m}$ elevation, Figure 2). Codrington Lagoon, a permanent marine to hypersaline lagoon fringed by dense mangroves, covers much of the western section of the island. The island's only settlement, Codrington Village, houses most of the island's c.200o inhabitants and is located on the eastern edge of the lagoon.

Based upon the Köppen-Geiger classification, Barbuda experiences an equatorial desert climate with distinct wet and dry seasons that occur during the boreal summer and winter, respectively (Kottek et al. 2006). Precipitation is relatively low because of its flat, low-lying 


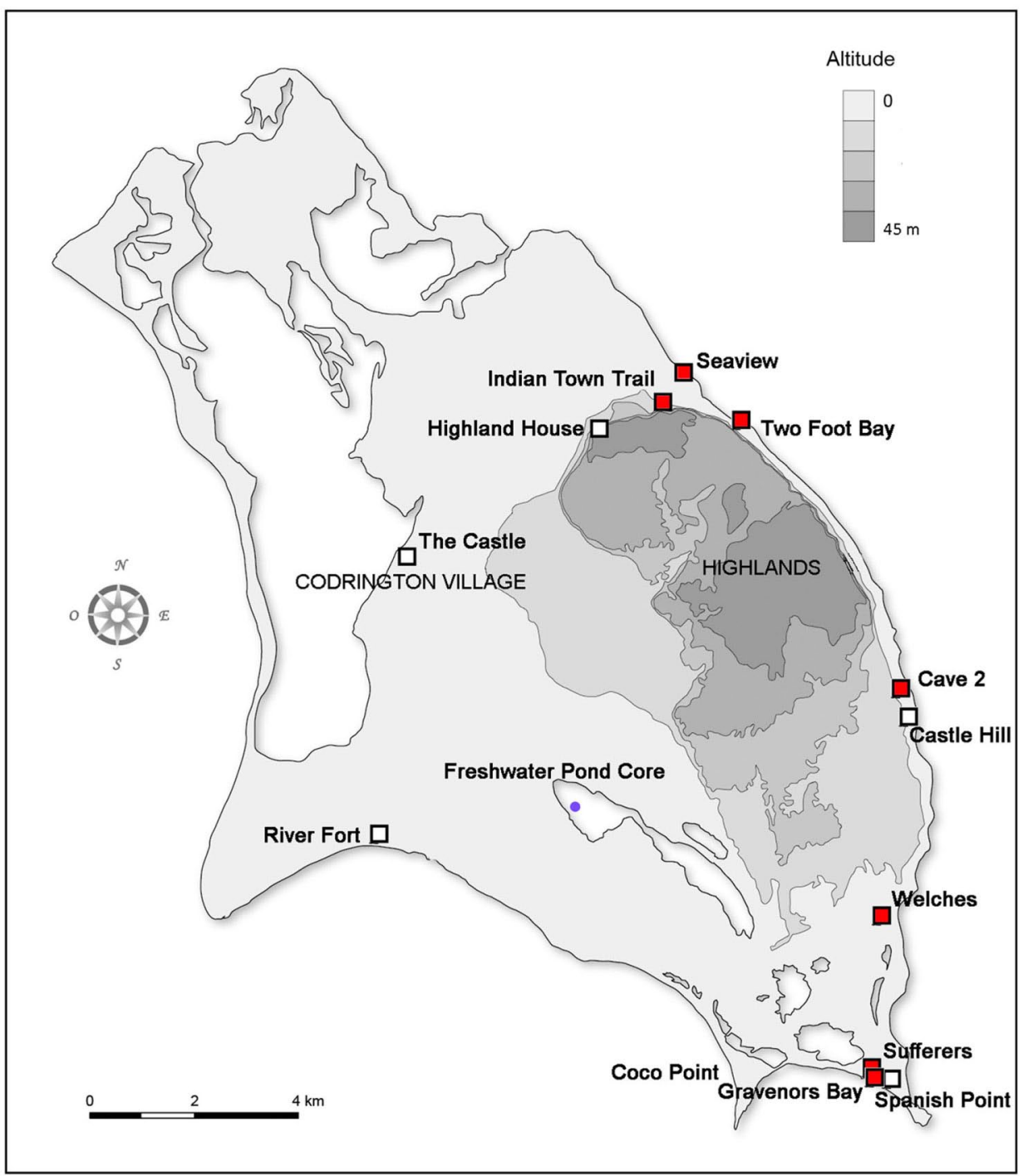

Figure 2. Map of Barbuda featuring archaeological sites and the sediment core sample location. Red squares indicate Ceramic Age sites, white squares are Colonial Period sites. The sediment coring (FP2) location is shown on Freshwater Pond.

topography. Nevertheless, heavy rainfall and thunderstorms occur episodically during hurricane season, spanning June through November. Barbuda's climate, shallow soils, and past land use are primary controls of the contemporary structure and floristic composition of plant communities on the island. Four main vegetation zones encompass the island, including succulent evergreen shrubland, which comprises the lowlands and coasts (Lindsay and Horwith 1997). Drought-deciduous 
and mixed evergreen-deciduous thorn woodland occupies the Highlands and areas near Freshwater Pond, with closed canopy broadleaved evergreen forests limited to solution holes of the Highlands and other lowland depressions with permanent access to water. Mangroves (Rhizophora mangle, Laguncularia racemosa, Avicennia germanins, and Conocarpus erectus) fringe the shorelines of Codrington lagoon and the island's ponds (including Freshwater Pond), and the eastern coastline. Sparsely vegetated dunes can be found on the northwestern and southeastern coasts (Areces-Mallea et al. 1999; Lindsay and Horwith 1997).

\section{Ceramic Age Occupations on Barbuda}

By 1300 BC, Archaic Age populations exploited the rich Queen Conch (Lobatus gigas) shell beds paralleling the island's southern beaches on a seasonal basis, according to archaeological data (Rousseau et al. 2017). The first known permanent settlements on Barbuda were established during the Ceramic Age around 100 BC. Ceramic Age populations of the Caribbean exploited marine resources and generally lived in large settlements with gardens, situated near the island's coasts (Bérard 2013; Curet and Oliver 1998). Later Ceramic Age peoples also lived on densely populated sites generally situated further inland (Bérard 2013; Bonnissent et al. 2007). While faunal analyses suggest that Ceramic Age Caribbean peoples exploited a wide variety of marine resources, their diet primarily comprised plant-based foods (Hofman 2013; Mickleburgh 2016).

Two of four identified Ceramic Age sites on Barbuda have been partially analyzed. Radiocarbon dates from the Seaview site (Figure 2) document an occupation from $100 \mathrm{BC}$ to $\mathrm{AD} 650$. To date, two middens, some possible cooking pits, and a large charred post have been excavated (Perdikaris et al. 2008, 2009). Deep stratified middens dating to AD 1130 have also been excavated at the Indian Town Trail site, located near the northern escarpment of the Highlands (Figure 2) (Perdikaris et al. 2008, 2009). The Late Ceramic Age Sufferers (c.AD 550-900) and Welches sites (Perdikaris, Look, and Hambrecht 2010; Vésteinsson 2011) are inland settlements situated on the southern part of the island (Figure 2) and have not been excavated. 


\section{Colonial Period Sites and Settlement}

Barbuda appears to have been unoccupied in the centuries preceding British colonization, a finding consistent with many of the Leeward Islands that appear to have been abandoned around AD 1300 for reasons that are not entirely understood (Wilson 2007). The first permanent settlement on Barbuda was established around 166o (Sainsbury 1893a) and by the 1670 s about 20 people lived on the island (Sainsbury 1893b, no. 1152). In 1673, Barbuda exported horses, cattle and sheep (Tweedy 1981). Under the management of the Codrington family from 1681 to 1870 , the island's primary function was provisioning livestock and crops to the Codrington plantations in Antigua and Barbados. Sugar cane was never grown on Barbuda, and the enslaved population participated in farming and herding activities, along with cutting wood, turtling and scavenging shipwrecks.

We examined two Colonial Period sites for this study: the Castle, located in Codrington Village, and Highland House, located on Highland Plateau (Figure 2). The Castle was the administrative center of Barbuda and used for storage, receiving visitors, and housing the island's managers (Headlam 1925, no. 441; Tweedy 1981, 169). Enslaved peoples also lived in the village, enclosed by a stone wall. In 1719 the population was listed as 92 slaves and 20 white servants, raising horses and black cattle (Headlam 1925, no. 441. i), and growing cotton and ginger (Gloucester Records Office (GRO) D1610 C3:75). Archeobotanical remains recovered from contexts adjacent to the Castle walls date to the early eighteenth century (Perdikaris, Look, and Hambrecht 2010).

The remains of 12 stone buildings are found at the Highland House site. Construction began around 1720 , followed by what appears to have been two or three building phases, with some buildings repurposed for different functions during the eighteenth century. The kitchen and an adjacent midden were sampled for archeobotanical remains. The kitchen contains an arched hearth with a bread oven that contained a single barley grain, a rare find in the region (Faucher, Bain, and Grimes 2017). Most artefacts recovered at Highland House date to the latter half of the eighteenth century. It seems the site was unoccupied from the late eighteenth or early nineteenth century onwards and by 1834 was described as a ruin (Watters and Nicholson 1982, 230). 
Repeated attacks from both European nations and Caribs led to the 1740 os construction of defensive batteries, Spanish Fort (located at Spanish Point) and River Fort on the southwest coast of the island (Watters 1997, 278, Figure 2). A 1750-1785 map from the Codrington Papers (Tweedy 1981) and an 1813 map (Figure 3) document the first Colonial Period use of the south coast and indicate the locations of these structures. Roads and a few fields on the 1813 map provide evidence of cultivation east of the village while symbols for vegetation cover the rest of the island. A late eighteenth century source states that from the Highlands 'when you look down upon the country from these higher lands as far as you can see appears covered with shrubs excepting [spurs?] and the roads' (GRO D1610 C21a).

\section{Charcoal Methodologies}

We analyzed charcoal from both sedimentary and archaeological contexts in order to study landscape change across all cultural occupations. We recovered an $84 \mathrm{~cm}$ sediment profile from Freshwater Pond (FP2), an inland pond surrounded by mangroves, using a Geocore Colinvaux-Vohnout piston corer. The stratigraphy, chronology, ostracod and gastropod assemblages, and oxygen isotope data from FP2 core were described by Burn et al. (2016).

We removed $1 \mathrm{~cm}^{3}$ samples at $1 \mathrm{~cm}$ intervals (except for depth levels 34-35, 49-50, and 53-54 cm which did not contain enough sediment) for macroscopic ( $>125 \mu \mathrm{m}$ ) charcoal analysis. Each sediment sample was soaked overnight in 5\% sodium metaphosphate to disperse clays and gently sieved through $125 \mu \mathrm{m}$ screens. Charcoal particles in the sieve contents were counted on gridded petri dishes under low magnification using a Leica stereozoom microscope to produce charcoal concentration (particles $/ \mathrm{cm}^{3}$ ). Sedimentary charcoal $>125$ $\mu \mathrm{m}$ represents local biomass burning, with most charcoal originating within a few hundred meters of fires (Conedera et al. 2009; Whitlock and Millspaugh 1996).

Preserved macrocharcoal from several types of features was examined from the Seaview, Indian Town Trail, Castle, and Highland House archaeological sites. All samples were manually floated (washover) using geological sieves of $4 \mathrm{~mm}$ to recover charcoal fragments, 


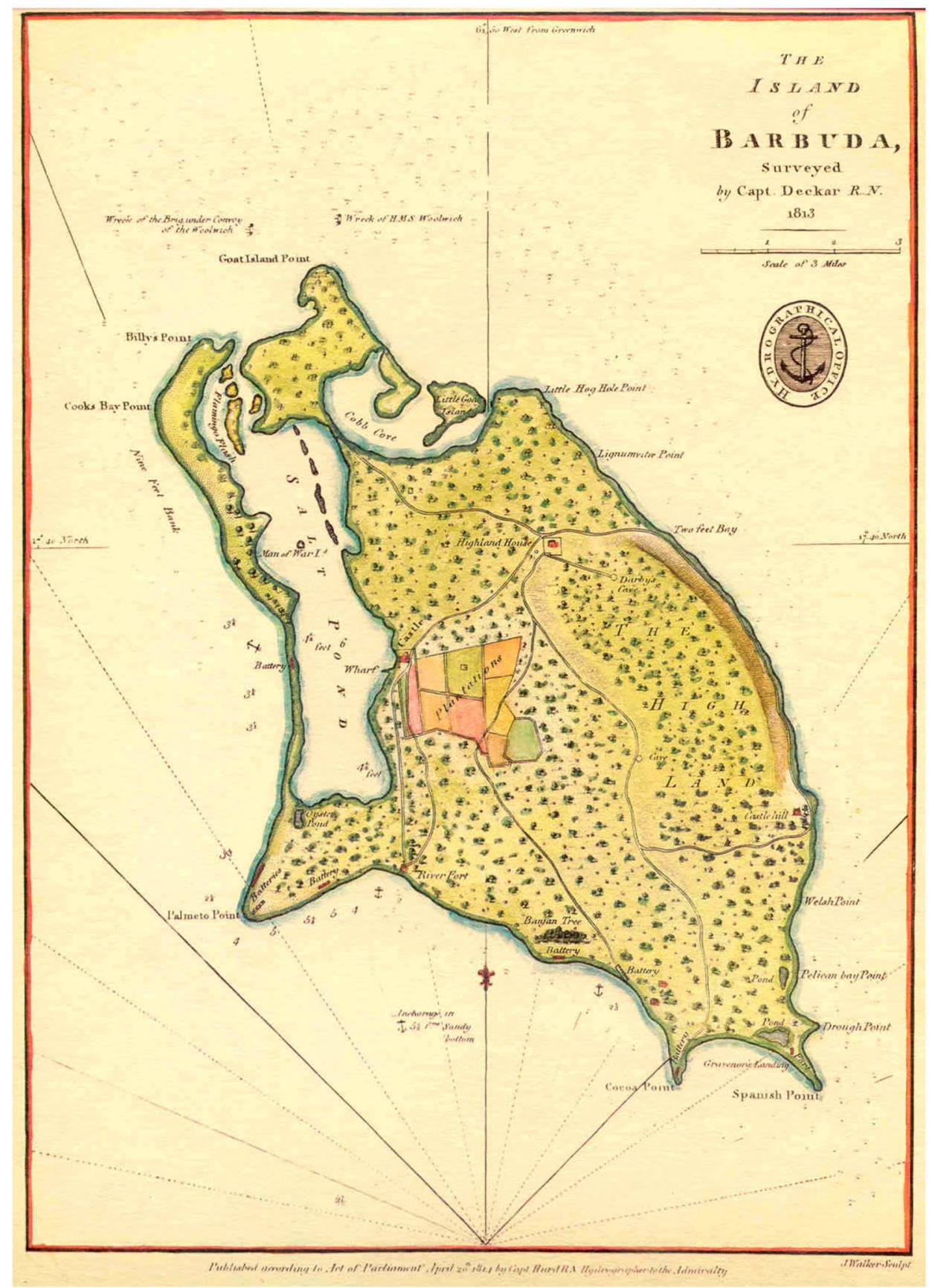

Figure 3. The Island of Barbuda, surveyed in 1813 by Capt. Deckar, R. N., Hydrographical Office (PRO, CO 700, MP/8 Antigua X/ 04800). 
following Pearsall (2000). Fragments were air-dried before identification, performed using cross, tangential and radial sections under a Zeiss high power light microscope (50-200x). All fragments were counted and weighed in grams. Identification was possible using Université Laval (Quebec, Canada) and University of Missouri-Columbia (USA) macrocharcoal reference collections, and the Inside Wood online database (2004). Growth rings were counted for minimal age and differentiation between roundwood (twigs and small branches) and timber (trunk) fragments. The inconsistency of sample size and proveniences creates statistical and interpretative biases resulting in interpretive challenges which are addressed by a presence-absence table (Table 1) for inter-site comparison, as seen elsewhere (e.g. Newsom and Wing 2004).

\section{Sedimentary Charcoal Results from Freshwater Pond}

Four accelerator mass spectrometry radiocarbon dates (Table 2) provided chronological control of the sediment profile with the basal radiocarbon date at $65 \mathrm{~cm}$ indicating that sediments began collecting at the core site well over 2000 years ago (Burn et al. 2016). Dates for sediments deposited below $65 \mathrm{~cm}$ are extrapolated assuming a sedimentation rate of $1 \mathrm{~cm} / 100$ years as estimated by the Burn et al. (2016) age-depth model for sediments in the adjacent section, 49$64 \mathrm{~cm}$.

Sedimentary charcoal concentrations varied substantially by sediment depth, ranging from an absence of charcoal fragments to a maximum of 905 particles per $\mathrm{cm}^{3}$ of sediment dating to $\mathrm{c} .36 \mathrm{o} \mathrm{BC}(67 \mathrm{~cm}$, Figure 4). Charcoal was absent to rare in the core from o to $37 \mathrm{~cm}$ (present day to c.AD 1650), while between AD 1345 and 1651, macrocharcoal fragments slightly increased in the core sediments, though remaining relatively low (maximum 30 pieces). The highest concentrations occur from $52 \mathrm{~cm}$ (c.AD 1250) to the end of the core $(84 \mathrm{~cm}$, over c.16o BC up to extrapolated c.206o+ yr BC). Peaks in charcoal concentration occurred from 51-53 cm (c.AD 1350-1150), 64-68 cm (c.AD 40-46o BC), 71-72 cm (c.86o BC), and 74-76 cm (c.106o-126o BC). 
Table 1. Trees and shrubs identified on Barbuda Ceramic Age and Colonial Period sites from charcoal remains.

\begin{tabular}{|c|c|c|c|c|c|}
\hline Taxa & $\begin{array}{l}\text { Common } \\
\text { name }\end{array}$ & Seaview & $\begin{array}{l}\text { Indian } \\
\text { Town Trail }\end{array}$ & The Castle & $\begin{array}{l}\text { Highland } \\
\text { House }\end{array}$ \\
\hline Amyris sp. & Torchwood & $x$ & $x$ & $x$ & $x$ \\
\hline Araliaceae & & & & $x$ & \\
\hline Avicennia nitida & Black Mangrove & & & $x$ & \\
\hline Bignoniaceae & & & $x$ & & \\
\hline Boraginaceae & & $x$ & & & \\
\hline Bucida sp. & Whitewood & $x$ & & & \\
\hline Capparidaceae & & & & $x$ & \\
\hline Capparis sp. & Capper & $x$ & & $x$ & $x$ \\
\hline Coccoloba sp. & Sea Grape genus & $x$ & & & $x$ \\
\hline Colubrina sp. & Soap Bush* & $x$ & & & $x$ \\
\hline Combretaceae & & & & $\mathrm{x}$ & $\mathrm{x}$ \\
\hline Conocarpus erectus & Button Mangrove & $x$ & & $x$ & $x$ \\
\hline Cordia sp. & & $x$ & & & \\
\hline Crescentia sp. & & & $\mathrm{X}$ & & \\
\hline Eugenia sp. & Stopper & $x$ & $x$ & $x$ & $\mathrm{x}$ \\
\hline Euphorbiaceae & & & & & $\mathrm{x}$ \\
\hline Exostema caribaeum & Greenheart* & $\mathrm{x}$ & $\mathrm{x}$ & $\mathrm{x}$ & $\mathrm{x}$ \\
\hline Fabaceae & & $x$ & & & $\mathrm{x}$ \\
\hline Ficus sp. & Fig & $x$ & & & \\
\hline Guaiacum officinale & Lignum Vitae & $\mathrm{X}$ & $\mathrm{X}$ & $\mathrm{x}$ & $\mathrm{x}$ \\
\hline Jacquinia cf. keyensis & Joewood & $x$ & & & $x$ \\
\hline Laguncularia cf. racemosa & White Mangrove & & & $x$ & \\
\hline Manilkara sp. & Sapodilla & & & & $\mathrm{x}$ \\
\hline Morella sp. & & $\mathrm{X}$ & & & \\
\hline Myrtaceae & Myrtle & $x$ & & $x$ & $x$ \\
\hline Quercus sp. & Oak & & & & $\mathrm{x}$ \\
\hline Rauvolfia sp. & & & & & $\mathrm{X}$ \\
\hline Rutaceae & & & & $x$ & $\mathrm{x}$ \\
\hline Tabebuia heterophylla & White Cedar & $\mathrm{x}$ & $\mathrm{x}$ & & \\
\hline Tabebuia sp. & & & & & $\mathrm{X}$ \\
\hline Tecoma stans & Yellow Bells & $x$ & & & \\
\hline Zanthoxylum sp. & & $x$ & & & \\
\hline Conifer indeterminate & Conifer & & & & $x$ \\
\hline
\end{tabular}

*Scientific and common name are based on Pratt et al. (2009), though common names may vary across the region. 
Table 2. FP2 $(0-84 \mathrm{~cm})$ radiocarbon date results through the facilities at the National Ocean Sciences Accelerator Mass Spectrometry Facility (NOMAS) at Woods Hole Oceanographic Institution and the Scottish Universities Environmental Research Centre (SUERC) at the University of Glasgow.

\begin{tabular}{|c|c|c|c|c|c|c|}
\hline Lab No. & $\begin{array}{l}\text { Depth } \\
(\mathrm{cm})\end{array}$ & Material dated & $\delta^{13} C(\% \circ)$ & ${ }^{14} \mathrm{C}$ yr BP & $\begin{array}{l}2 \sigma \text { Calibrated } \\
\text { yr } A D\end{array}$ & $\begin{array}{r}\text { Probability } \\
\text { (\%) }\end{array}$ \\
\hline \multirow[t]{5}{*}{ SUERC-37169 } & $27-30$ & Ruppia maritima achenes & -15 (est.) & $242 \pm 30$ & $1936-1954$ & 7.4 \\
\hline & & & & & $1762-1802$ & 28.0 \\
\hline & & & & & 1738-1751 & 0.9 \\
\hline & & & & & $1631-1682$ & 52.4 \\
\hline & & & & & $1525-1558$ & 6.7 \\
\hline \multirow[t]{2}{*}{ SUERC-37170 } & $47-49$ & Ruppia maritima achenes & -15 (est.) & $347 \pm 30$ & $1463-1533$ & 39.1 \\
\hline & & & & & $1536-1635$ & 55.8 \\
\hline \multirow[t]{2}{*}{ OS-81963 } & $63-64$ & Woody fragment & -25.17 & $1959 \pm 30$ & $103-122$ & 4.4 \\
\hline & & & & & $40 \mathrm{BC}-88$ & 91.0 \\
\hline \multirow[t]{3}{*}{ OS-81964 } & $64-65$ & Woody fragment & -26.05 & $2121 \pm 40$ & $211-42$ BC & 83.1 \\
\hline & & & & & $229-220 \mathrm{BC}$ & 0.9 \\
\hline & & & & & $352-295 \mathrm{BC}$ & 11.4 \\
\hline
\end{tabular}

Notes: Calibrated sample ages were determined by the OxCal 4.1 software package (Ramsey 2001) using the Intcal09 dataset (Reimer et al. 2011) and modeled in Clam 2.1 (Blaauw 2010). Table adapted from Burn et al. 2016.

\section{Results of Macrocharcoal Analyses from Four Archaeological Sites on Barbuda}

At the Seaview site, we analyzed 77 different contexts from both inland and ocean facing areas including middens, possible cooking pits, and living areas. Results indicate that site occupants used at least 19 different woody taxa, represented by a total of 4244 fragments (865 g, Table 1). Of these, 751 fragments (346 g) come from a single charred wooden post of lignum vitae (Guaiacum officinale). Four taxa were ubiquitous across all archaeological sites: lignum vitae, stopper (Eugenia sp.), greenheart (Exostema caribaeum) and torchwood (Amyris sp.). Lignum vitae is a drought-resistant hardwood species found in lowland dry forests and coastal areas, while stopper, greenheart and torchwood are found on arid soils and on limestone. Stopper and torchwood are both used as fuel sources and for fashioning wooden posts, while greenheart was exploited for timber (Pratt et al. 2009; The Wood Database 2007; Useful Tropical Plants Database 


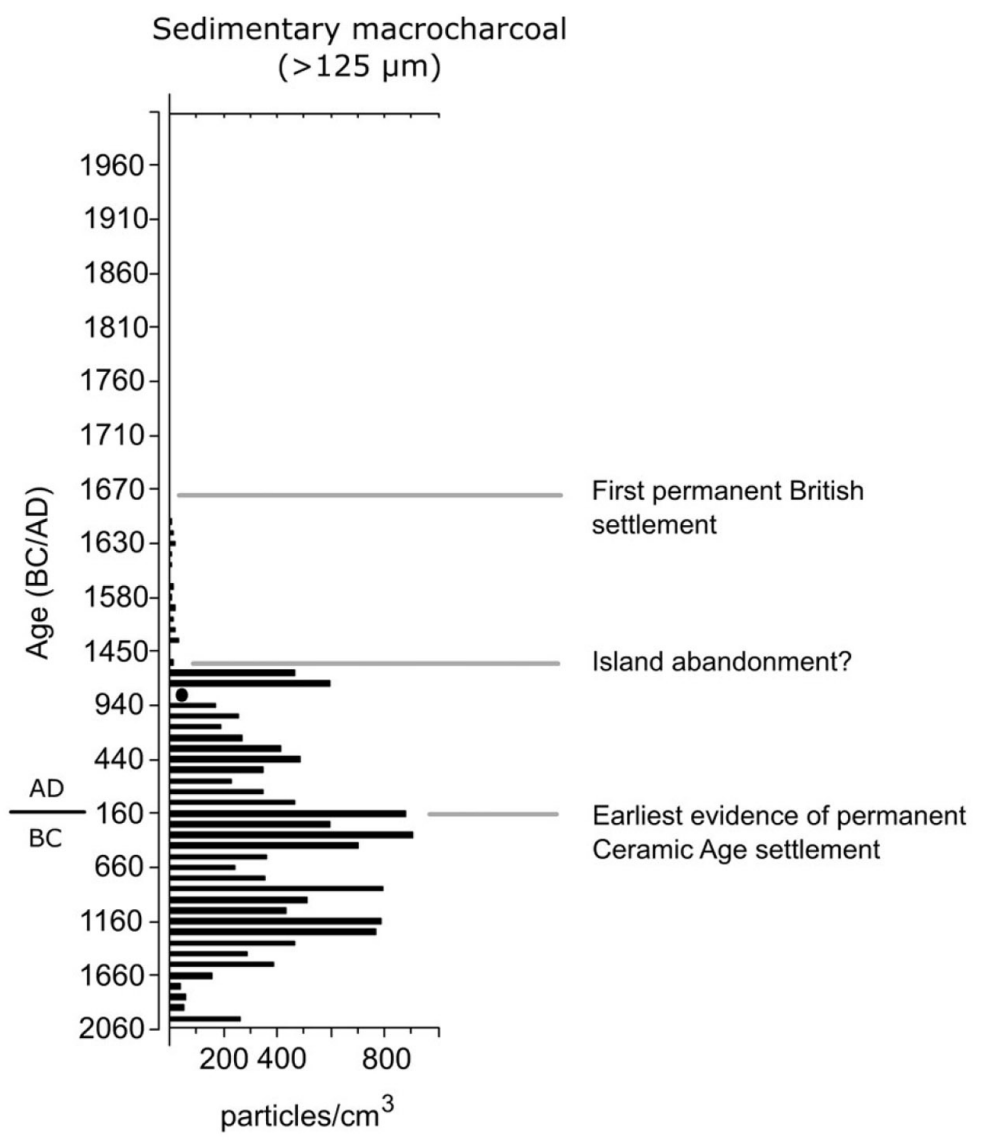

Figure 4. Freshwater Pond 2 sediment core macroscopic charcoal concentration. Black circle notes presence of macroscopic charcoal though sample depth did not contain enough sediment to perform a full count to determine concentration.

2014). These descriptions are consistent with our interpretation of the archaeological macrocharcoal data, which suggest that Seaview occupants used these wood types for construction, tools and fuel materials.

Nine samples from the stratified midden at Indian Town Trail contained a total of 31 macrocharcoal fragments (1.366 g) representing at least seven taxa (Table 1). The four most abundant taxa observed at Seaview were also present, though in much smaller quantities. Growth ring counts indicated minimal ages between 6 and 9 years in these four taxa, with the exception of a single torchwood specimen with three rings. Four of these charcoal fragments were roundwood (small trees or tree branches). 
Five samples from the Castle site yielded 283 macrocharcoal fragments (35.525 g) representing at least 13 different taxa (Table 1 ). The Combretaceae family (white mangrove family) was the most abundant taxon, though torchwood, stopper, greenheart, and lignum vitae were also present. Small roundwood fragments are present in very low quantities while timber was more abundant. The minimal age of all taxa varied between 2 and 15 growth rings.

A total of 17 samples from Highland House contained 735 fragments (63.210 g) from 19 taxa. Torchwood, stopper, greenheart, and lignum vitae were present along with button mangrove (Conocarpus erectus) and seagrape (Coccoloba sp.). An indeterminate conifer yielded 183 fragments (11.094 g), most of which (150 fragments or $8.066 \mathrm{~g}$ ) were found in the hearth of the bread oven. Timber macrocharcoal fragments were the most abundant, though roundwood accounts for $23 \%$ of the macrocharcoal identified at Highland House, the highest percentage noted from the four sites under discussion.

\section{Human-Induced Landscape Transformation on Barbuda}

Taken together, our archeological and paleoecological charcoal data along with archival sources document the island's vegetation and its exploitation over 3000 years. The presence of large $(>125 \mu \mathrm{m})$ sedimentary charcoal fragments in most samples representing periods before AD 1650 in the FP2 core (Figure 4) suggests regular biomass burning of island vegetation by Ceramic and possibly by Archaic Age inhabitants. Increases in lake sediment charcoal in lowland Caribbean island sites have been interpreted as evidence of human occupation and biomass burning (Burney, Burney, and MacPhee 1994; Kjellmark 1996) or tied to changes in climate that influence natural ignitions (Caffrey and Horn 2015; Higuera-Gundy et al. 1999). In the case of Freshwater Pond, the archaeological record of human presence on Barbuda strengthens the sedimentary charcoal link to human activities.

We are unsure how much of the Archaic Age is represented by the FP2 core, because sediment ages below $65 \mathrm{~cm}$ are extrapolated. Our extrapolated basal core date of around $2000 \mathrm{BC}(84 \mathrm{~cm})$ could be much earlier or later. Even so, we know that some interval of the charcoal-rich lower core (Figure 4) represents this earliest period of 
human occupation. While the archaeological data to date suggest only seasonal exploitation of Barbuda coasts during the Archaic Age for the collection of conch meat (Rousseau et al. 2017), further research may identify domestic sites from this time period. Their identification, along with abundant sedimentary charcoal, may infer the use of terrestrial resources.

The archaeological record of the arrival of Ceramic Age peoples by c.100 BC aligns well with our lowest calibrated radiocarbon date that places the charcoal-rich $64-65 \mathrm{~cm}$ interval at between 40 and 350 BC. Sedimentary macroscopic $(>125 \mu \mathrm{m})$ charcoal is often deposited within a few hundred meters of a fire and thus, in Freshwater Pond, may represent burning of the mangroves or other adjacent vegetation. Charcoal may also have been transported from burned slopes south or west of the Highlands by precipitation events. Most of our sedimentary charcoal fragments fell into the $>125^{-250} \mu \mathrm{m}$ size class, which has been found to be wind-transported for several kilometers in the western U.S. (Whitlock and Millspaugh 1996). Perhaps, easterly trade winds or strong onshore sea breezes transported some charcoal fragments from fires in Ceramic Age sites in southeastern Barbuda to Freshwater Pond. Some (or all) of the high charcoal amounts from $65 \mathrm{~cm}$ (or lower) through $52 \mathrm{~cm}$ (AD 1350-1150) may be evidence that Ceramic Age populations strategically burned vegetation to clear land for villages and gardens in conjunction with sustainable marine foraging strategies. The sedimentary charcoal signature in the lower FP2 core is consistent with Ceramic Age horticulturalists living in large communities, though understanding intentional burning is complex and at times poorly understood. Vegetation accumulation after site abandonment may also result in a significant fuel accumulation, contributing to charcoal signatures via increases in natural ignition (Pyne 1998, 73).

Whether all of the FP2 charcoal peaks signals human-ignited fires is not yet clear. Some changes in sedimentary charcoal abundance may relate to fluctuations in the number of natural ignitions associated with climatic shifts. Evaluation of additional proxies and new archaeological information may help to disentangle the human-ignited fires from any natural drivers of fire.

Following the Ceramic Age and apparent abandonment of the island, sedimentary charcoal concentrations dropped dramatically and 
remained consistently low for four centuries preceding the arrival of the British settlers in the first half of the seventeenth century. We interpret this sharp drop in charcoal as evidence of a dramatic decrease in burning near Freshwater Pond and the surrounding lowlands after abandonment. Continued low sedimentary charcoal deposition (charcoal was absent from many samples), during the Colonial Period indicated a continued reduction in burning. In the absence of fire and other indicators of large-scale land clearance, and low resource exploitation by the island's relatively small population, vegetation communities likely regenerated on abandoned villages sites and their adjacent lands. Vegetation succession on the island is supported by historical sources that document the regular export of wood for construction and firewood along with timber salvaged from shipwrecks (Tweedy 1981) and an 1813 map which documents cultivated lands restricted to the vicinity of Codrington Village (Figure 3).

Wood macrocharcoal from the four archaeological sites indicates the intentional selection of wood varieties for domestic use. While the samples exhibit some inter-site variability, the four wood taxa present across all sites: torchwood, stopper, greenheart, and lignum vitae, reflect the dry Barbudan landscape. Recovered macrocharcoal from the Seaview and Indian Town Trail sites indicate wood selection related to domestic requirements including cooking, fuel, and construction, confirmed by the lignum vitae charcoal recovered from a posthole at Seaview. Torchwood, sea grape and stopper are also sources of fresh fruit, while both stopper and lignum vitae are known for their medicinal properties (Newsom 2006). The 19 taxa represented by charcoal from Seaview reflect the exploitation of the coastal landscape, suggested by the presence of sea grape and button mangrove. The Indian Town Trail site has fewer wood taxa, but this is likely due in part to the smaller sample volumes treated. Nevertheless, both sites have distinct charcoal signatures related to their immediate vegetation (coastal versus lowland). These sites differ from charcoal assemblages identified on Ceramic Age sites on Nevis, though key coastal species such as sea grape and more dry lowland species such as stopper and lignum vitae are found on both islands during this period (Newsom 2006; Newsom and Pearsall 2003).

The Highland House and Castle site macrocharcoal assemblages also suggest local collection of wood for domestic activities, while 
wood clearance during the Colonial Period may be signaled by the ubiquitous presence of lignum vitae across all sites, although it is not common on Barbuda today. This interpretation is consistent with research on Nevis suggesting that lignum vitae was extensively harvested during the Colonial Period and was likely an important component of Caribbean lowland dry forests before extensive exploitation (Newsom 2006, 137). Wood is regularly mentioned in the Codrington account books, which note the export of firewood, charcoal, and construction timber to Codrington plantations in Antigua and Barbados, along with the collection of wood from shipwrecks (Tweedy 1981, 128). Non-native tree species, such as oak (Quercus sp.) and conifers found at Highland House may have been imported as building materials or salvaged from shipwrecks. Five wood samples including oak (Quercus sp.) and pine (Pinus sp.) sampled from standing historic structures on Barbuda led Watters and Miller (2000) to similar conclusions.

A detailed map from 1813 indicated that parts of the Barbudan landscaped were cleared for farming and herding. Cotton, ginger, and potatoes, mentioned in the Codrington Papers, were grown on the island, while other crops, such as barley (Hordeum vulgare L.), were imported (Faucher, Bain, and Grimes 2017). As farming and herding activities contribute to the unintentional introduction of weeds and other invasive species (Rapaport 2006), these resulted in the delayed succession of native vegetation seen across parts of the island and contributed to the introduction of species such as thorny acacia. This has also been documented on the nearby islands of Nevis and St. Martin (Newsom 2006).

In summary, human transformation of the Barbudan landscape began during the Ceramic Age, as it did on other Caribbean islands (Newsom 2006, 2008; Siegel et al. 2015), coinciding with the arrival of a sedentary population. Plant use was complex and involved multiple sources including prepared fields, home gardens and taxa gathered in the wild (Newsom 2008). We propose that landscape modification on Barbuda occurred sporadically on patchy spatial scales as local sites were occupied and abandoned and subsistence strategies shifted through the Archaic and Ceramic Ages and into the early Colonial period. A few centuries of abandonment after Ceramic Age occupation caused the most abrupt shift in fire regime and allowed for 
regrowth of woody species that became important resources for later British colonists. During the Colonial Period, wood was harvested selectively and primarily for export rather than strategically burned for agricultural clearing, keeping fires in check. Coastal vegetation was most favored and depleted by Colonial harvesting practices. Exploitation of specific trees, such as mangroves and lignum vitae, probably modified existing plant communities, rather than causing new vegetation states on a broad scale, until agriculture and herding activities during the 1800 s caused substantial declines in native species, concomitant with the introduction of weeds and invasive species.

\section{Conclusion}

Sustained high macrocharcoal concentrations in the Freshwater Pond sediment core suggest strategic burning by Ceramic Age horticulturalists. This was followed by reduced burning during the pre-Columbian abandonment and the Colonial period, during which extensive horticultural activities and burning may have shifted to a greater emphasis on herding activities and wood harvest for building and export.

Properly assessing impacts of colonialism using charcoal data and written sources remains a challenge. The abundant Codrington $\mathrm{Pa}-$ pers and historic sources provide a parallel, though partial narrative for the use of wood resources on the island. Hardwood species were selected for timber export, while a wider variety was used for domestic use and charcoal production. The Colonial Period did not impose the drastic transformation seen on other islands where landscapes were significantly transformed in order to establish sugar and coffee plantations (Watts 1987), rather it was more of a transition to a mixed economy of herding, farming, and wood cutting. These activities on the central and southern sections of the islands resulted in a progressive transformation of Barbuda's vegetation, as wood resources were harvested, invasive plant species were introduced, and grazing by livestock animals likely prevented regeneration of native vegetation (Harris 1965).

This multidisciplinary approach to understanding human-environment interactions on Barbuda demonstrates the value of analyzing multiple data sources collected both on and adjacent to archaeological 
sites to reconstruct comprehensive and accurate histories of environmental change. To date, the FP2 core is the only sediment core examined at high ( $1 \mathrm{~cm}$ intervals) resolution in this region; the detailed charcoal profile clearly documents past fire events. The expansion of sediment analysis and archaeological work to other sites on the island would provide the spatial and temporal coverage needed to properly assess the impacts of Archaic Age peoples on the Barbudan landscape, refine the nature and timing of cultural shifts, and to further clarify patterns and drivers of landscape transformation.

Acknowledgments We thank Dr Reginald Murphy, and the Barbuda Council for their support and a special thanks to Mr Calvin Gore for sharing his knowledge of the island with us. We appreciate suggestions from Dr Lee Newsom and an anonymous reviewer that improved this paper.

Disclosure Statement No potential conflict of interest was reported by the authors.

Funding This project was funded in part by the Social Science and Humanities Research Council of Canada (SSHRC) via a Research Development Initiatives Grant to Bain (PI), Kennedy, and Burn (820-2010-0189) and via SSHRC Doctoral funding to Faucher.

\section{Notes on contributors}

Allison Bain is a Full Professor at Université Laval in the Département des Sciences historiques and the CELAT research centre at Universite Laval, Canada. She is also a member of the Barbuda Research Center, Antigua and Barbuda.

Anne-Marie Faucher is a doctoral candidate at Université Laval, Canada.

Lisa M. Kennedy is an Associate Professor in the College of Natural Resources and Environment at Virginia Tech University, USA.

Allison R. LeBlanc is a doctoral candidate at Virginia Tech University, USA.

Michael J. Burn is a Lecturer in the Department of Geography and Geology at the University of the West Indies, Jamaica.

Rebecca Boger is an Associate Professor of Earth and Environmental Sciences at Brooklyn College, USA, and a member of the Barbuda Research Center, Antigua and Barbuda.

Sophia Perdikaris is a Full Professor in the Department of Anthropology at Brooklyn College, USA, and director of the Barbuda Research Center, Antigua and Barbuda. 


\section{References}

Areces-Mallea, A. E., A. S. Weakley, X. Li, R. G. Sayre, J. D. Parrish, C. V. Tipton, and T. Boucher. 1999. "A guide to Caribbean vegetation types: preliminary classification system and descriptions.” The Nature Conservancy. Electronic Document. Accessed April 6, 2017. https://www.conservationgateway.org/ ConservationByGeography/NorthAmerica/Documents/A-Guide-to-CaribbeanVegetation-Types.pdf

Armstrong, D. 2013. "New Directions in Caribbean Historical Archaeology." In The Oxford Handbook of Caribbean Archaeology, edited by W. F. Keegan, C. L. Hofman and R. Rodríguez Ramos, 525-542. New York: Oxford University Press.

Bérard, B. 2013. “The Saladoid.” In The Oxford Handbook of Caribbean Archaeology, edited by W. F. Keegan, C. L. Hofman and R. Rodríguez Ramos, 184-197. New York: Oxford University Press.

Blaauw, M. 2010. "Methods and Code for 'classical' Age- Modelling of Radiocarbon Sequences.” Quaternary Geochronology 5: 512-518.

Bonnissent, D., P. Bertran, D. Galop, D. Imbert, and C. Strouvenot. 2007. Chronologie des occupations précolombiennes de l'île Saint-Martin (Petites Antilles) et relations avec les paléoenvironnements. Proceedings of the International Congress for Caribbean Archaeology 21, St. Augustine, Trinidad, Tobago.

Britt, S. F. 2010. "Fueling the Fire: Examining Caribbean Colonial Relations between Humans and the Environment." Historical Archaeology 44: 54-68.

Burn, M., J. Holmes, L. M. Kennedy, A. Bain, J. D. Marshall, and S. Perdikaris. 2016. "A Sediment-Based Reconstruction of Caribbean Effective Precipitation during the Little Ice Age from Freshwater Pond, Barbuda.” The Holocene 26 (8): 1237-1247.

Burney, D. A., L. P. Burney, and R. D. E. MacPhee. 1994. "Holocene Charcoal Stratigraphy from Laguna Tortuguero, Puerto Rico, and the Timing of Human Arrival on the Island." Journal of Archaeological Science 21 (2): 273-281.

Caffrey, M., and S. Horn. 2015. "Long-term Fire Trends in Hispaniola and Puerto Rico from Sedimentary Charcoal: A Comparison of Three Records.” The Professional Geographer 67 (2): 229-241.

Codrington Papers. 2016. “Codrington Papers, West Indies Correspondence." Simon Fraser University Digital collection. Electronic Document. Accessed February 10, 2017. http://digital.lib.sfu.ca/cwc-collection

Conedera, M., W. Tinner, C. Neff, M. Meurer, A. F. Dickens, and P. Krebs. 2009. "Reconstructing Past Fire Regimes: Methods, Applications, and Relevance to Fire Management and Conservation." Quaternary Science Reviews 28: 555-576.

Curet, A. L., and J. R. Oliver. 1998. "Mortuary Practices, Social Development, and Ideology in Pre-Columbian Puerto Rico.” Latin American Antiquity 9: 217-239.

Faucher, A.-M., A. Bain, and V. Grimes. 2017. "First Archaeological Evidence for Old World Crops in the Caribbean: The Presence of Barley on the Island of Barbuda." Historical Archaeology 51 (4). 
Fitzpatrick, S. M., and W. F. Keegan. 2007. "Human Impacts and Adaptations in the Caribbean Islands: An Historical Ecology Approach." Earth and Environmental Science Transactions of the Royal Society of Edinburgh 98 (01): 29-45.

Harris, D. R. 1965. "Plants, Animals, and Man in the Outer Leeward Islands: An Ecological Study of Antigua, Barbuda, and Anguilla." University of California Publications in Geography 18: 1-164.

Hauser, M. W., and D. Hicks. 2007. "Colonialism and Landscape: Power, Materiality and Scales of Analysis in Caribbean Historical Archaeology." In Envisioning Landscape: Situations and Standpoints in Archaeology and Heritage, edited by D. Hicks, L. McAtackney and G. Fairclough, 251-274. Walnut Creek, CA: Left Coast Press.

Headlam, C., ed. 1925. "America and West Indies: June 1712. British History Online. Calendar of State Papers Colonial." America and West Indies, 1711-1712, Vol. 26, pp. 293-310. Electronic Document. Accessed June 19, 2014. http:// www.british-history.ac.uk/report.aspx? compid $=73893$

Higuera-Gundy, A., M. Brenner, D. A. Hodell, J. H. Curtis, Barbara W. Leyden, and Michael W. Binford. 1999. "A 10,300 ${ }^{14} \mathrm{C}$ yr Record of Climate and Vegetation Change from Haiti." Quaternary Research 52: 159-170.

Hofman, C. L. 2013. "The Post-Saladoid in the Lesser Antilles (A.D. 600/8001492)." In The Oxford Handbook of Caribbean Archaeology, edited by W. F. Keegan, C. L. Hofman and R. Rodríguez Ramos, 205-220. New York: Oxford University Press.

Inside Wood. 2004. InsideWood Database at North Carolina State University. Electronic Document. Accessed October 24, 2016. http://insidewood/lib.ncsu. edu/search

Keegan, W. F., C. L. Hofman, and R. Rodríguez Ramos. 2013. "Introduction." In The Oxford Handbook of Caribbean Archaeology, edited by W. F. Keegan, C. L. Hofman and R. Rodríguez Ramos, 1-18. New York: Oxford University Press.

Kjellmark, E. 1996. "Late Holocene Climate Change and Human Disturbance on Andros Island, Bahamas.” Journal of Paleolimnology 15: 133-145.

Kottek, M., J. Grieser, C. Beck, B. Rudolf, and F. Rubel. 2006. "World Map of the Köppen-Geiger Climate Classification Updated.” Meteorologische Zeitschrift 15: 259-263.

Lindsay, K., and B. Horwith. 1997. A Vegetation Classification of Antigua-BarbudaRedonda: Implications for Conservation. St. Thomas, U.S. Virgin Islands: Eastern Caribbean Biodiversity Programme, Biodiversity Publication 2.

Mickleburgh, H. L. 2016. "Dental Wear and Pathology in the Precolonial Caribbean: Evidence for Dietary Change in the Ceramic Age.” International Journal of Osteoarchaeology 26: 290-302.

Newsom, L. A. 2006. "Tubers, Fruits, and Fuel: Paleoethnobotanical Investigations of the Dynamics between Culture and the Forested Environment on Nevis, Lesser Antilles." In The Prehistory of Nevis: a Small Island in the Lesser Antilles, edited by S. M. Wilson, 103-144. New Haven, CT: Peabody Museum of Natural History Publications, Yale University Press. 
Newsom, L. A. 2008. "Caribbean Paleoethnobotany: Present Status and New Horizons (Evolution of an Indigenous Ethnobotany)." In Crossing the Borders: New Methods and Techniques in the Study of Material Culture in the Caribbean, edited by C. Hofman, 173-194. Tuscaloosa: University of Alabama Press.

Newsom, L. A., and D. Pearsall. 2003. "Trends in Caribbean Island Archaeobotany." In People and Plants in Ancient Eastern North America, edited by P. Minnis, 347-412. Washington, DC: Smithsonian Institution Press.

Newsom, L., and E. S. Wing. 2004. Land and Sea: Native American Uses of Biological Resources in the Caribbean. Tuscaloosa: University of Alabama Press.

Pagán-Jiménez, J. R. 2011. "Early Phytocultural Processes in the pre-Colonial Antilles." In Communities in Contact: Essays in Archaeology, Ethnohistory and Ethnography of the Amerindian Circum-Caribbean, edited by C. L. Hofman and A. van Duijvenbode, 87-116. Leiden: Sidestone Press.

Pagán-Jiménez, J. R. 2013. "Human-Plant Dynamics in the Precolonial Antilles: A Synthetic Update." In The Oxford Handbook of Caribbean Archaeology, edited by W. F. Keegan, C. L. Hofman and R. Rodríguez Ramos, 391-406. New York: Oxford University Press.

Pearsall, D. M. 200o. Palaeoethnobotany: A Handbook of Procedures. 2nd ed. San Diego, CA: Academic Press.

Perdikaris, S., C. Look, and G. Hambrecht. 2010. Barbuda Historical Ecology Project 2010 Report. Unpublished report on file, Barbuda Research Center/City University of New York.

Perdikaris, S., T. McGovern, M. Brown, C. Look, D. McGovern, A. Pálsdóttir, and K. Smiarowski. 2008. Field Report, Barbuda Historical Ecology Project 2008. Unpublished report on file, Barbuda Research Center/City University of New York.

Perdikaris, S., T. McGovern, G. Hambrecht, C. Look, and N. Manigault. 20o9. Field Report, Barbuda Historical Ecology Project 2009. Unpublished report on file, Barbuda Research Center/City University of New York.

Pratt, C., K. Lindsay, M. Pearson, and C. Thomas. 2009. The Wild Plants of Antigua and Barbuda: An Illustrated Field Guide to the Native and Naturalised Vascular Plants. Antigua: Environmental Awareness Group.

Pyne, S. J. 1998. “Forged in Fire, Land, and Anthropogenic Fire.” In Advances in Historical Ecology, edited by W. Balée, 64-103. New York: Columbia University Press.

Ramsey, C. B. 2001. "Development of the Radiocarbon Calibration Program." Radiocarbon 43: 355-363.

Rapaport, M. 2006. "Eden in Peril: Impact of Humans on Pacific Island Ecosystems." Island Studies Journal 1: 109-124.

Reimer, P. J., M. G. L. Baillie, E. Bard, A. Bayliss, J. W. Beck, P. G. Blackwell, C. Bronk Ramsey, et al. 2011. "IntCalog and Marineog Radiocarbon Age Calibration Curves, o-50,000 Years cal BP.” Radiocarbon 51: 1111-1150.

Rousseau, V., A. Bain, J. Chabot, S. Grouard, and S. Perdikaris. 2017. "The Role of Barbuda in the Settlement of the Leeward Islands: Lithic and Shell Analysis Along the Strombus Line Shell Midden." Journal of Caribbean Archaeology 17: $1-25$. 
Sainsbury, W. N. 1893a. America and West Indies: April 1676. British History Online, Calendar of State Papers Colonial, America and West Indies, 1675-1676 and Addenda 1574- 1674, Vol 9, pp. 365-388. Electronic Document. Accessed June 19, 2014. www.british-history.ac.uk/cal-state-papers/colonial/americawest-indies/volg/pp365-388.

Sainsbury, W. N., ed. 1893b. America and West Indies: April 1676. British History Online, Calendar of State Papers Colonial, America and West Indies, 16751676 and Addenda 1574-1674, Volume 9, pp. 494-507. Electronic Document. Accessed June 19, 2014.

Siegel, P. E., J. G. Jones, D. M. Pearsall, N. P. Dunning, P. Farrell, N. A. Duncan, J. H. Curtis, and S. K. Singh. 2015. "Paleoenvironmental Evidence for First Human Colonization of the Eastern Caribbean.” Quaternary Science Reviews 129: 275-295.

The Wood Database. 2007. Accessed November 1, 2016. http://www.wooddatabase.com

Tweedy, M. T. 1981. "A History of Barbuda under the Codringtons 1738-1833." Unpublished PhD thesis, University of Birmingham.

Useful Tropical Plants Database. 2014. Accessed September 1, 2014. http:// tropical.theferns.info

Vésteinsson, O. 2011. Reconnaissance of a Prehistoric Shell-Ridge in Barbuda, West Indies. Rapport on file, Barbuda Research Center, Codrington.

Watters, D. R. 1997. "Historical Documentation and Archaeological Investigation of Codrington Castle, Barbuda, West Indies." Annals of the Carnegie Museum 66: 231-288.

Watters, D. R., and R. B. Miller. 200o. "Wood Identification in Historic Sites: Inferences for Colonial Trade and Modification of Vegetation on Barbuda." Caribbean Journal of Science 36 (1-2): 19-30.

Watters, D. R., and D. V. Nicholson. 1982. "Highland House, Barbuda: An 18th Century Retreat.” The Florida Anthropologist 35: 223-242.

Watts, D. 1987. The West Indies: Patterns of Development, Culture and Environmental Change Since 1492. Cambridge: Cambridge University Press.

Whitlock, C., and S. H. Millspaugh. 1996. "Testing the Assumptions of Fire-History Studies: An Examination of Modern Charcoal Accumulation in Yellowstone National Park, USA.” The Holocene 6: 7-15.

Wilson, S. M. 2007. The Archaeology of the Caribbean. New York: Cambridge University Press. 